\title{
Modelling heat stress on livestock: how can we reach long-term and global coverage?
}

\section{David Leclère \& Petr Havlík} Ecosystems Services \& Management Program (ESM) International Institute for Applied Systems Analysis (IIASA), Austria

Presentation at the 2016 LiveM conference, Potsdam (Germany) 15-16 th June 2016

leclere@iiasa.ac.at

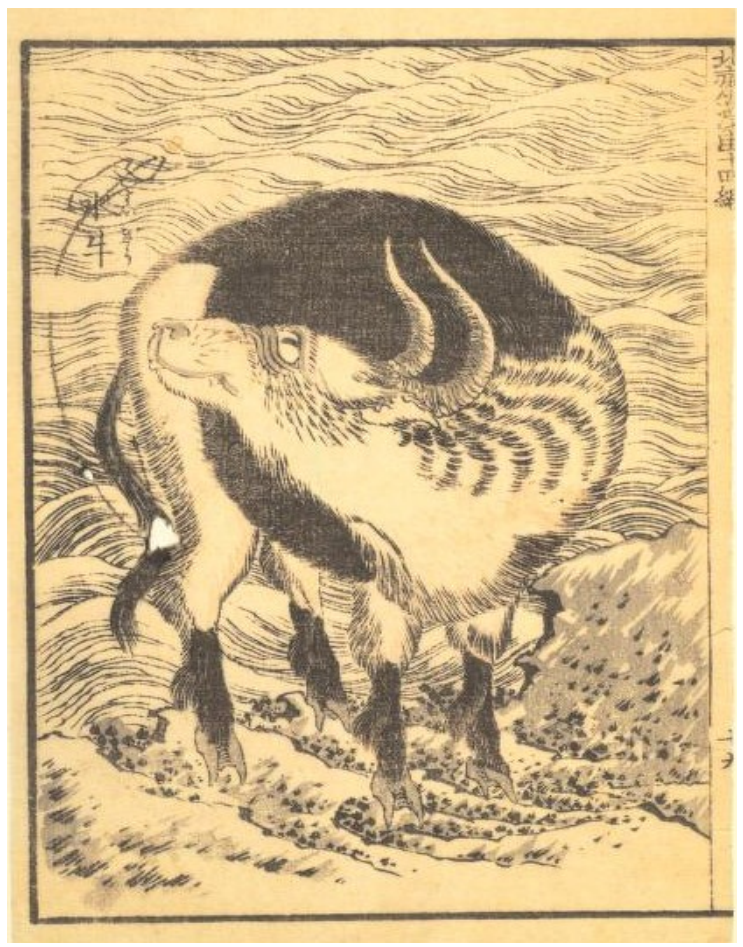




\section{Introduction}




\section{Introduction}

- Exposure to heat stress is a large geo. driver of current global livestock:

- "The thermal environment is the most important ecological factor determining the growth, development, and productivity of domestic animals." (Collier \& Gebremedhin, 2015)

- "Heat is a major constraint on animal productivity in the tropical belt and arid areas [...]. The effect of heat stress is also substantial in the subtropical-Mediterranean zones [...]" (Silanikove, 2000) 


\section{Introduction}

- Exposure to heat stress is a large geo. driver of current global livestock

- Effects of heat stress on livestock is a long-studied topic (incl. models)

Reviews of the progress of dairy science

Section A. Physiology. Gattle in a hot environment

BY W. BIANCA

Review

Heat stress in cattle and the effect of shade on production and behaviour: a review

Judith K. Blackshaw ${ }^{\mathrm{A}}$ and A. W. Blackshaw ${ }^{\mathrm{B}}$

Thermal balance of livestock

1. A parsimonious model

J.R. Turnpenny ${ }^{\mathrm{a}, 1}$, A.J. McArthur ${ }^{\mathrm{b}}$, J.A. Clark ${ }^{\mathrm{a}}$, C.M. Wathes ${ }^{\mathrm{c}, *}$ 


\section{Introduction}

- Exposure to heat stress is a large geo. driver of current global livestock

- Effects of heat stress on livestock is a long-studied topic (incl. models)

- It can have significant economic impacts on the livestock sector

J. Dairy Sci. 86:(E. Suppl.):E52-E77

(C) American Dairy Science Association, 2003.

St-Pierre, Cobanov \& Schnitkey (2003)

\section{Economic Losses from Heat Stress by US Livestock Industries ${ }^{1}$}

N. R. St-Pierre*, B. Cobanov*, and G. Schnitkey†

*Department of Animal Sciences

The Ohio State University, Columbus, $\mathrm{OH} 43210$

†Department of Agricultural and Consumer Economics University of Illinois, Urbana, IL 61801

- "Across the United States, heat stress results in estimated total annual economic losses to livestock industries that are between \$1.69 and \$2.36 billion" (per year)

- Already accounting for adaptations

- In one of the countries having highest ability to adapt 


\section{Introduction}

- Exposure to heat stress is a large geo. driver of current global livestock

- Effects of heat stress on livestock is a long-studied topic (incl. models)

- It can have significant economic impacts on the livestock sector

- Yet, no global picture of current \& future heat stress impact on livestock

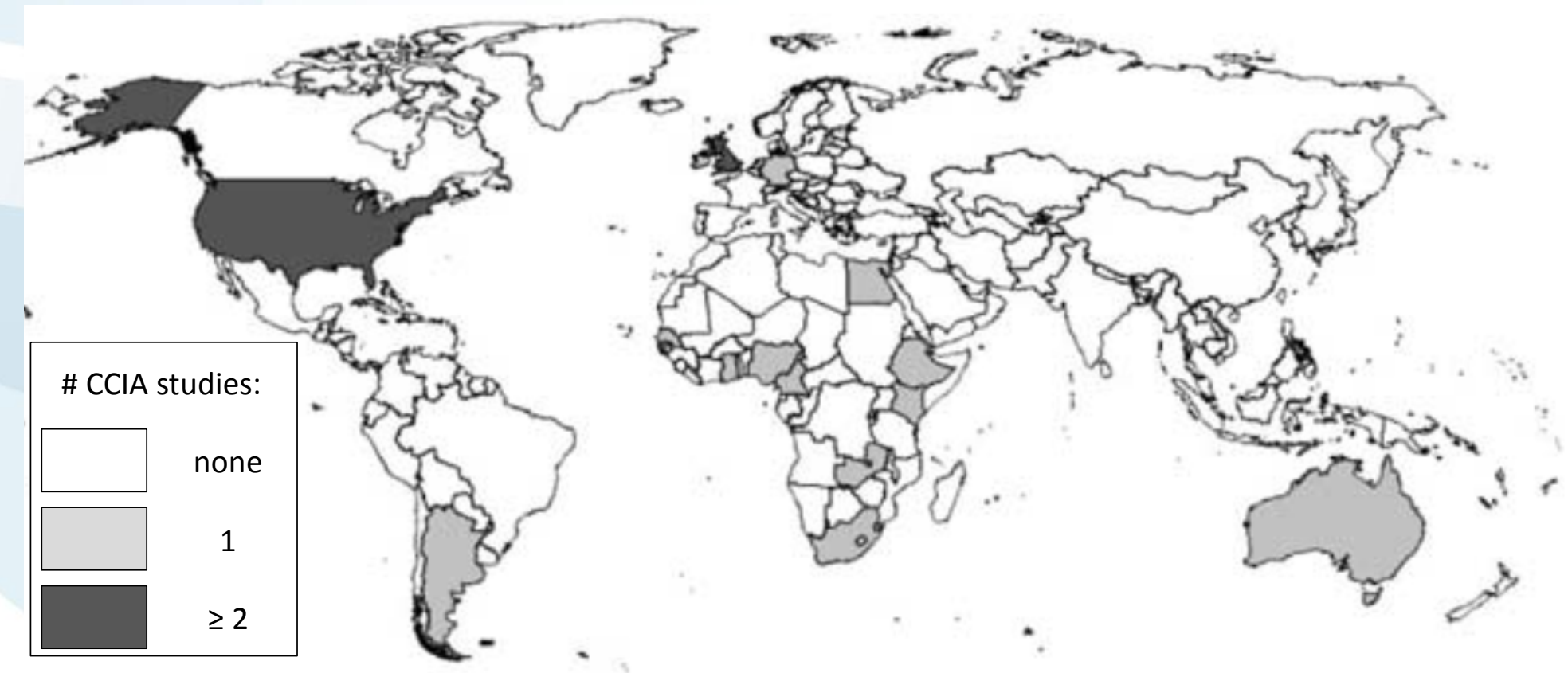

Adapted from Gauly et al. (2013), based on data from Martinsohn \& Hansen (2012) 


\section{Introduction}

- Exposure to heat stress is a large geo. driver of current global livestock

- Effects of heat stress on livestock is a long-studied topic (incl. models)

- It can have significant economic impacts on the livestock sector

- Yet, no global picture of current $\&$ future heat stress impact on livestock

- Exposure to heat stress is expected to change considerably
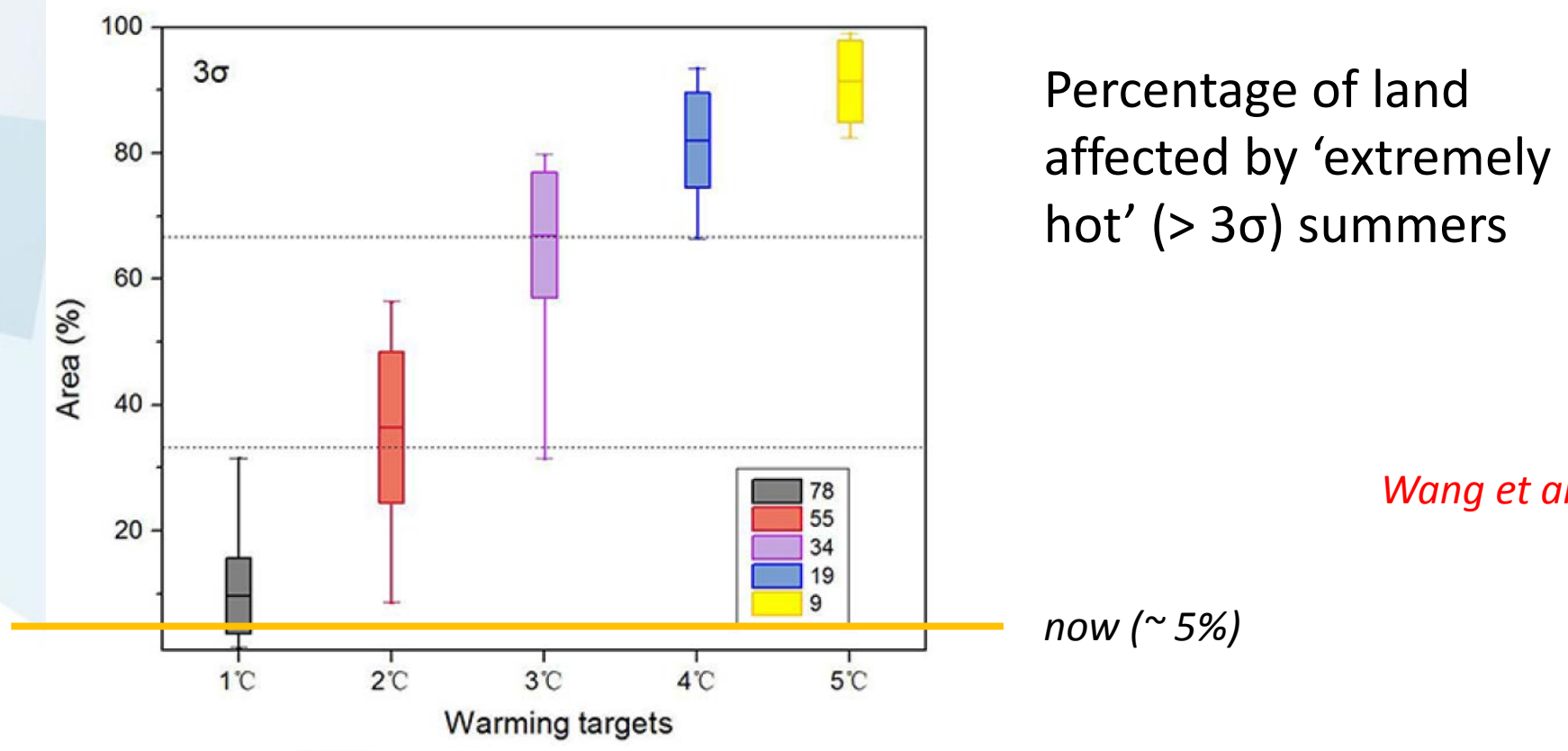

Wang et al. (2015)

now ( 5\%) 


\section{Introduction}

- Exposure to heat stress is a large geo. driver of current global livestock

- Effects of heat stress on livestock is a long-studied topic (incl. models)

- It can have significant economic impacts on the livestock sector

- Yet, no global picture of current $\&$ future heat stress impact on livestock

- Exposure to heat stress is expected to change considerably

How to bring modeling tools to

these scales (global, long-term)? 


\section{Relevant processes at various scales}




\section{Relevant processes at various scales}

- The principle of heat stress for livestock

- Normal condition (TNZ): homeothermy easy to maintain

adapetd from

Silanikove

(2000)

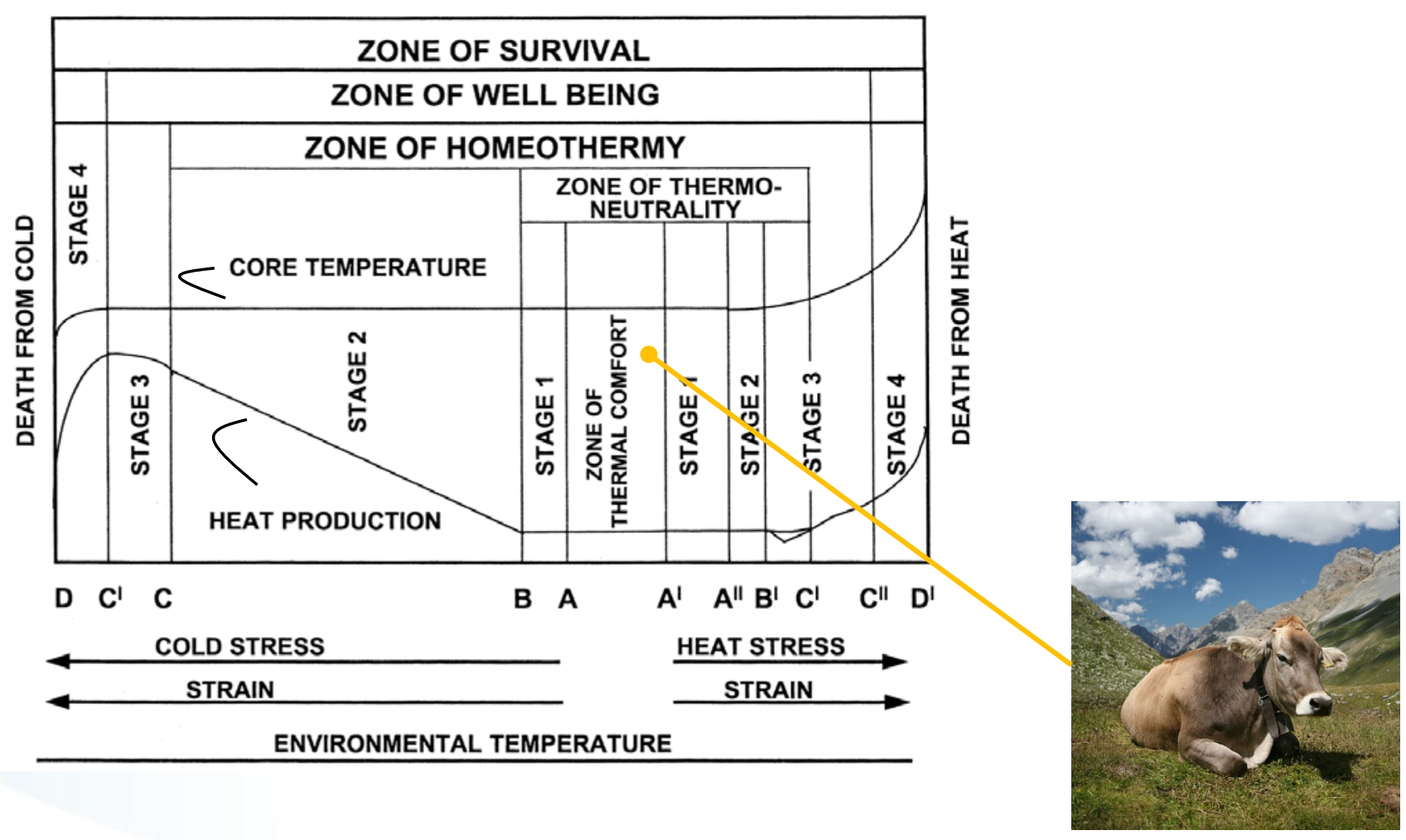




\section{Relevant processes at various scales}

- The principle of heat stress for livestock

- Normal condition (TNZ): homeothermy easy to maintain

- Heat stress condition (outside TNZ): homeothermy strains animal or broken

adapetd from

Silanikove

(2000)
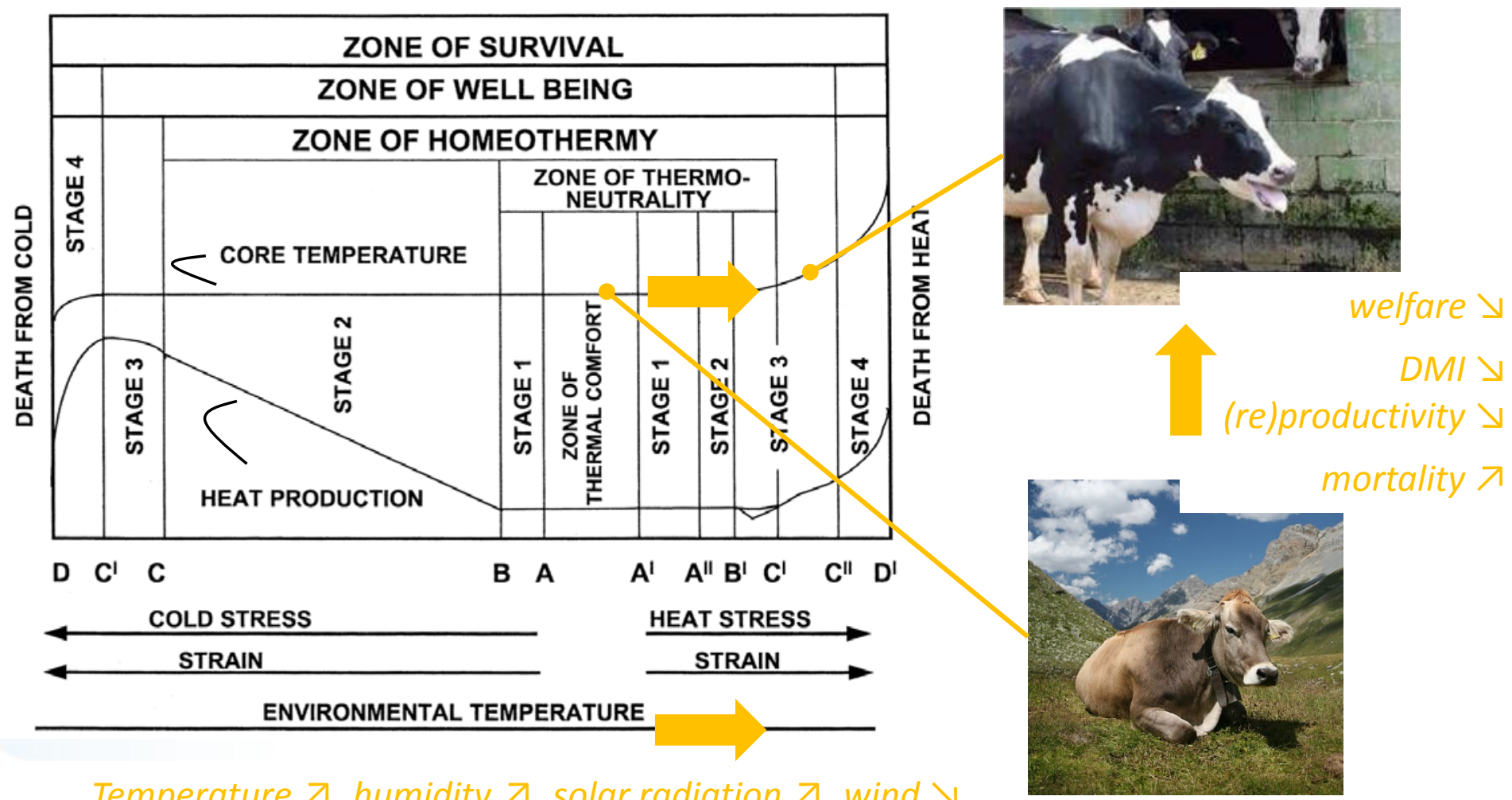

Temperature $\lambda$, humidity $\lambda$, solar radiation $\lambda$, wind $\searrow$ 


\section{Relevant processes at various scales}

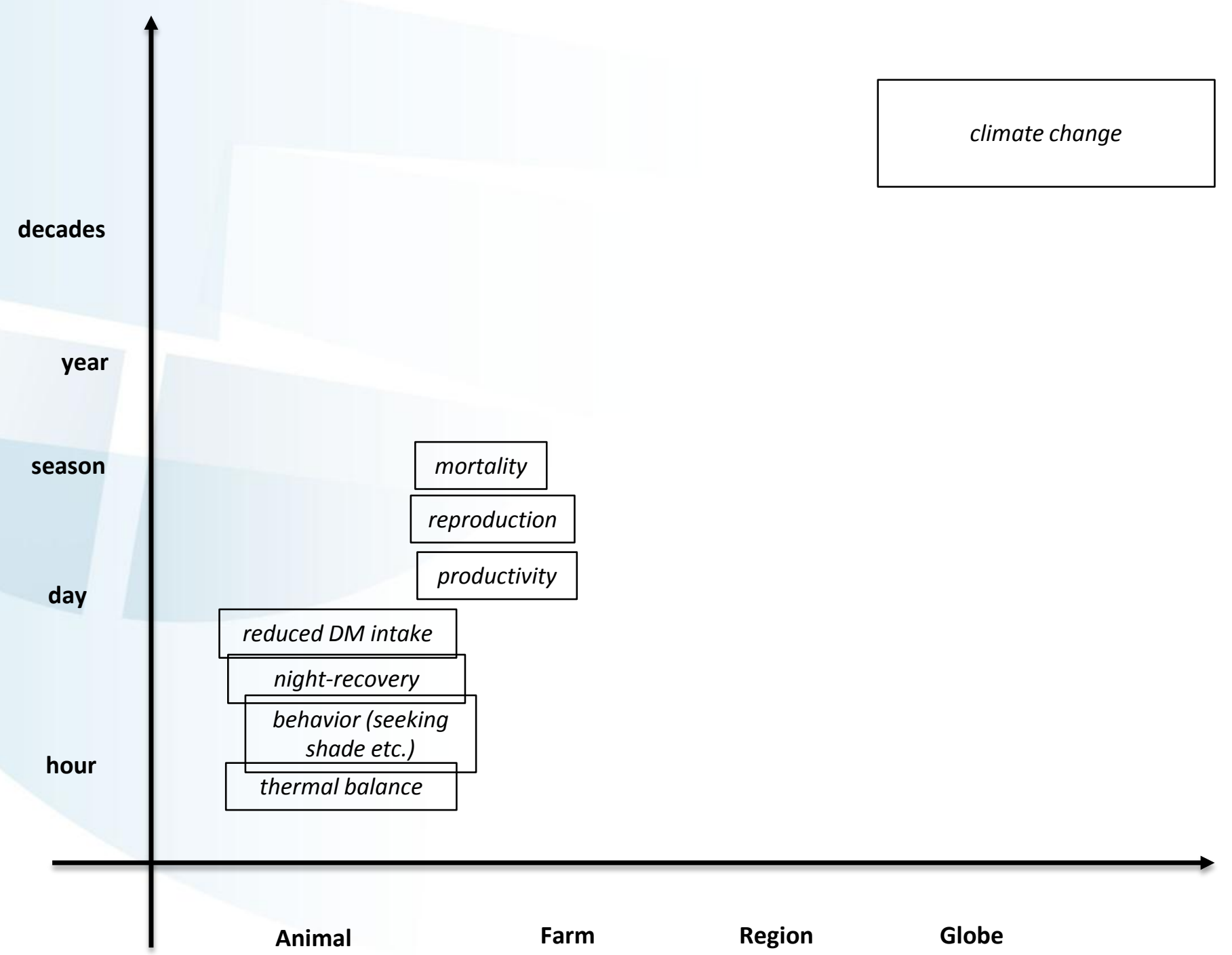




\section{Relevant processes at various scales}

\section{Extending to season \& year time scale:}

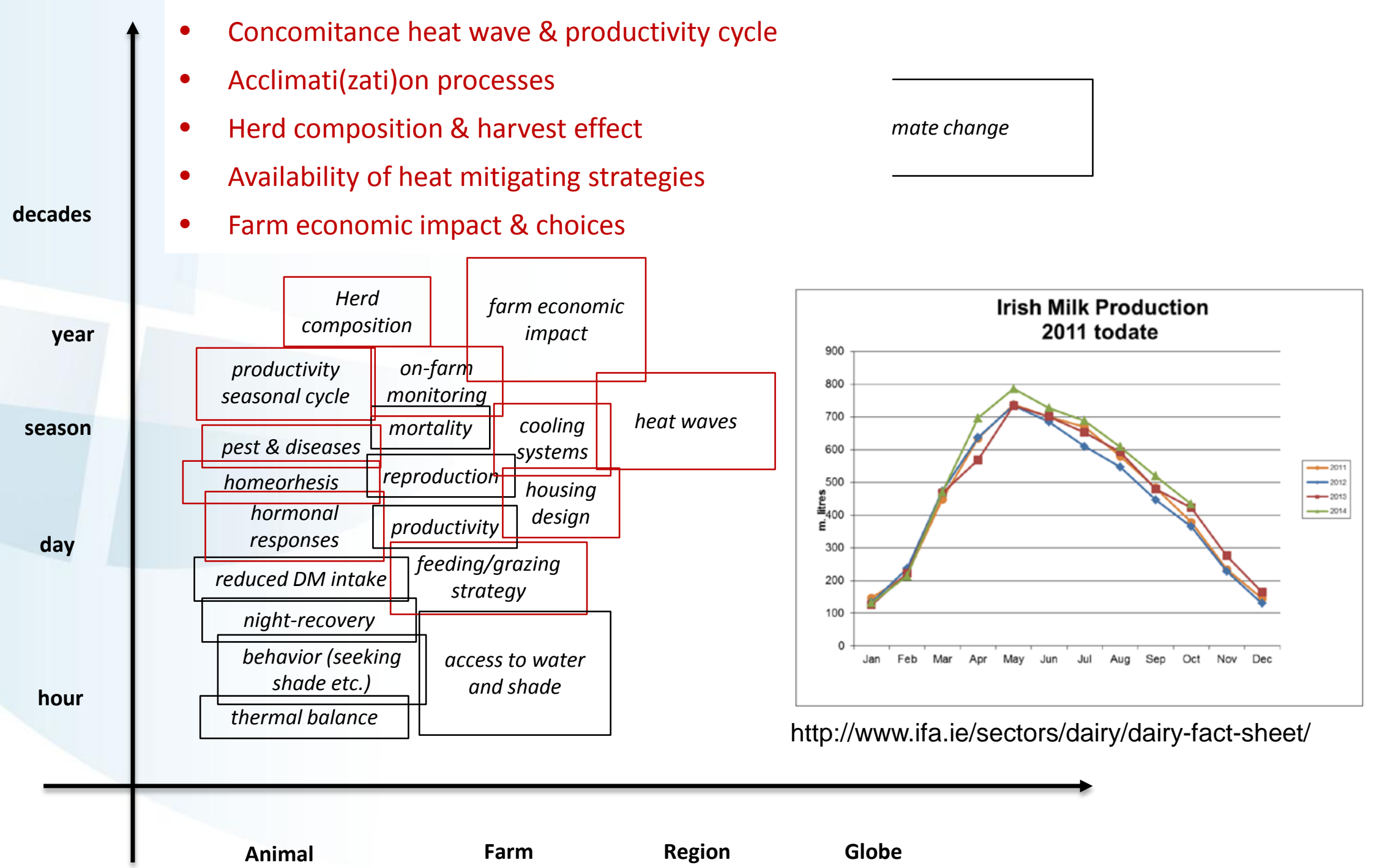




\section{Relevant processes at various scales}

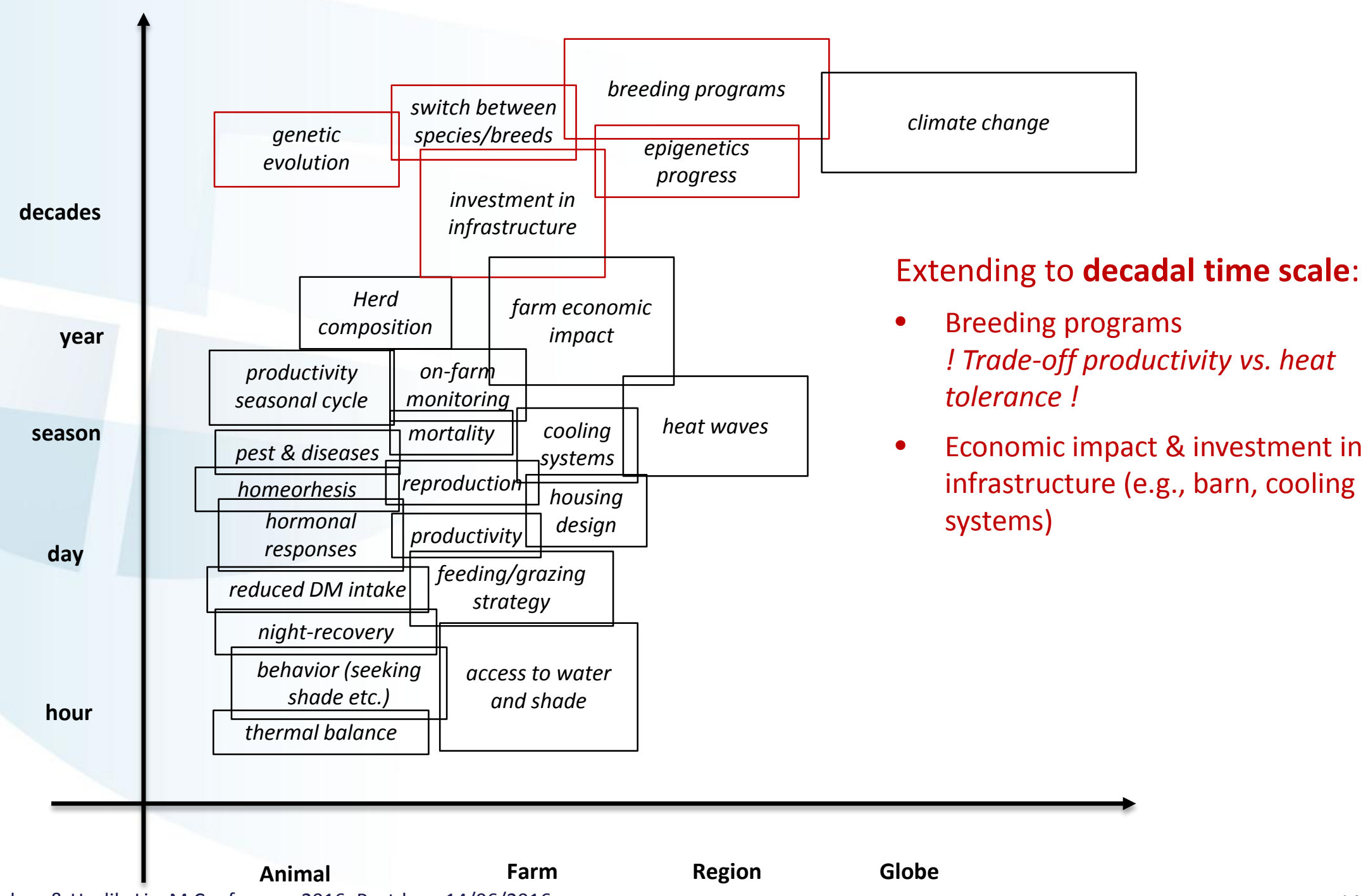




\section{Relevant processes at various scales}

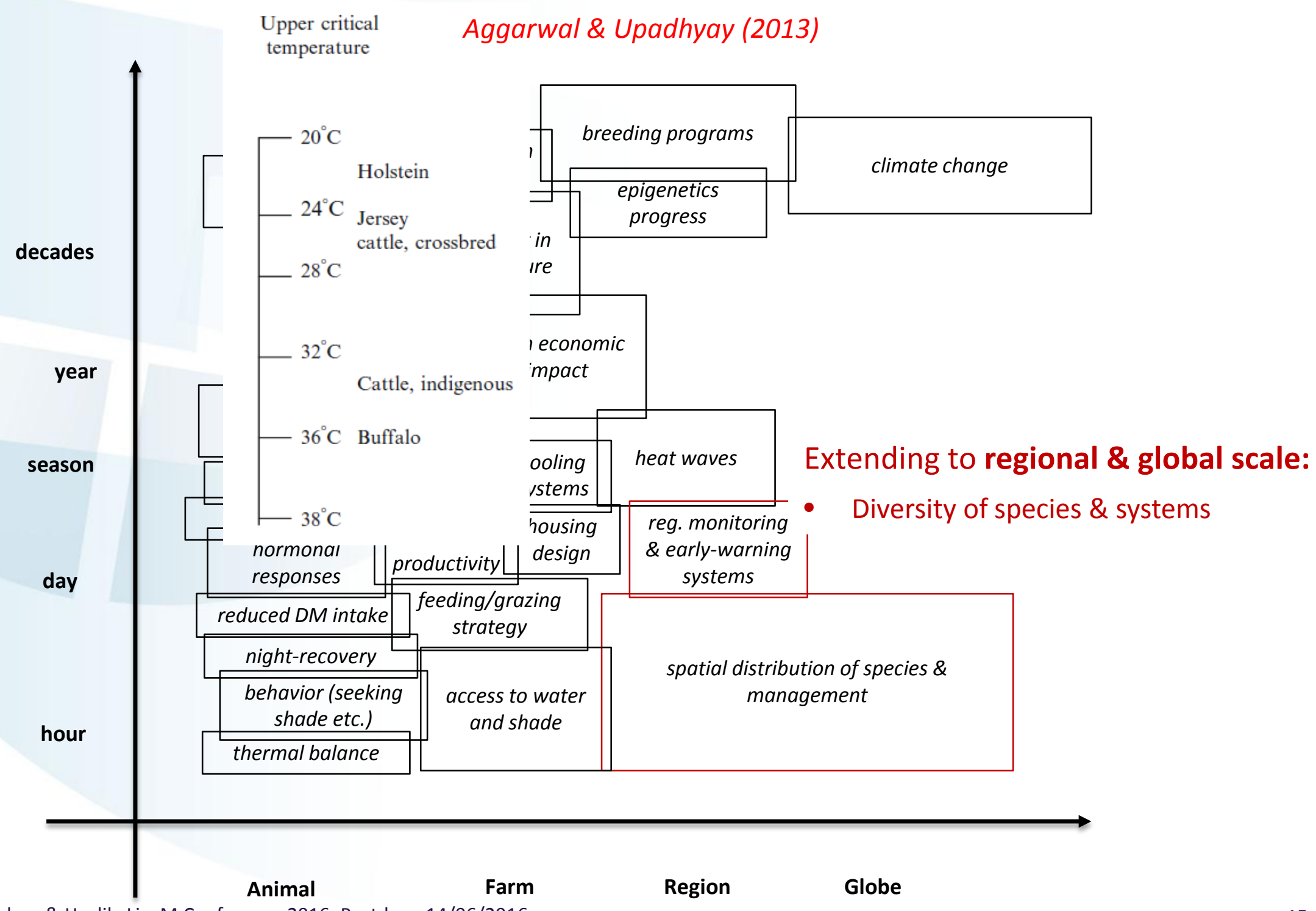




\section{Relevant processes at various scales}

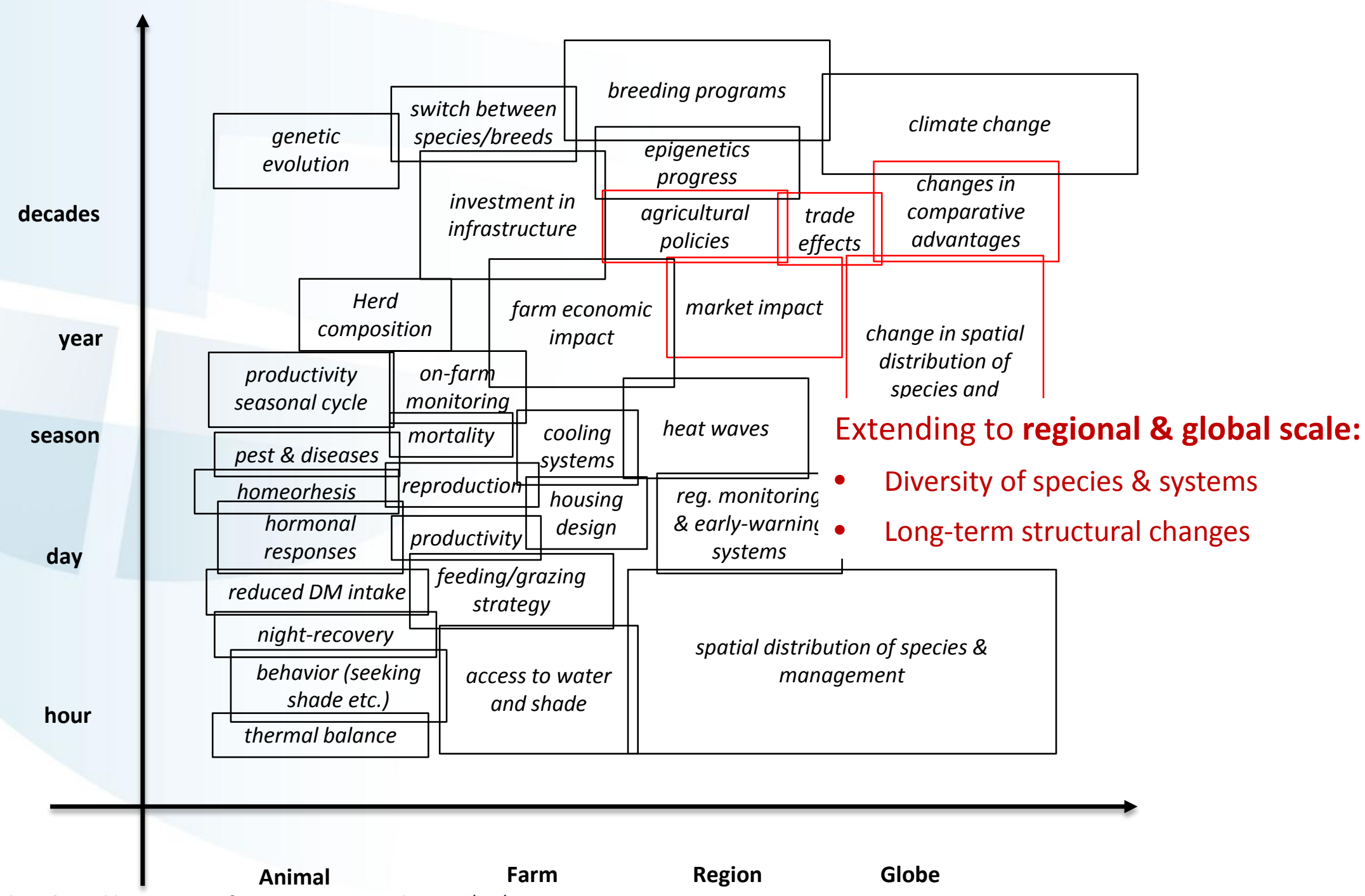




\section{A review of existing models}




\section{A brief overview of existing models}

\section{- Type I (thermal balance)}

\section{- Complex mechanistic model of thermal exchange routes}

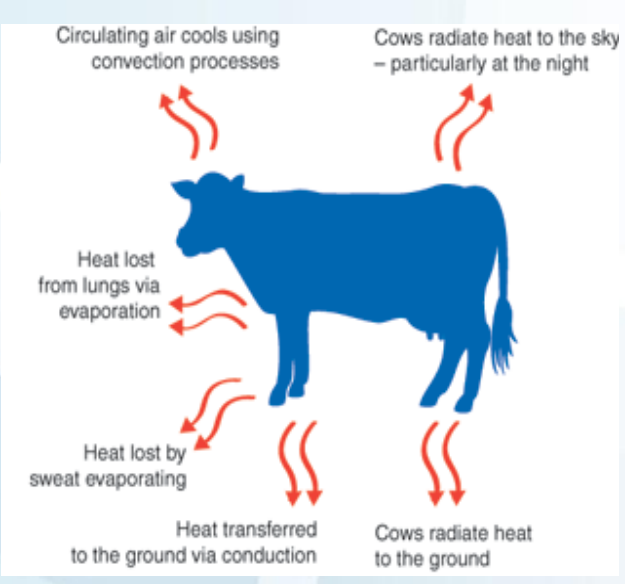

http://www.coolcows.com.au/cows-andheat/heat-exchange.htm

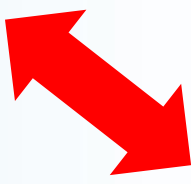

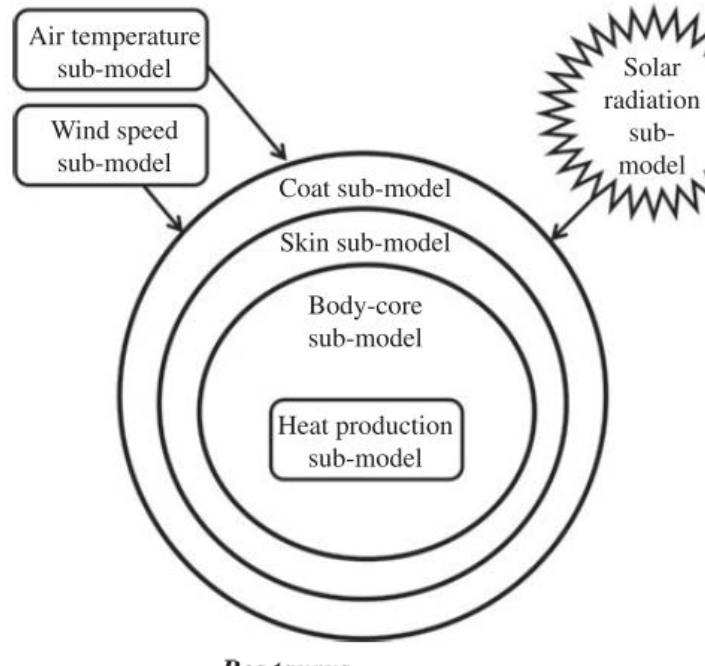

Bos taurus

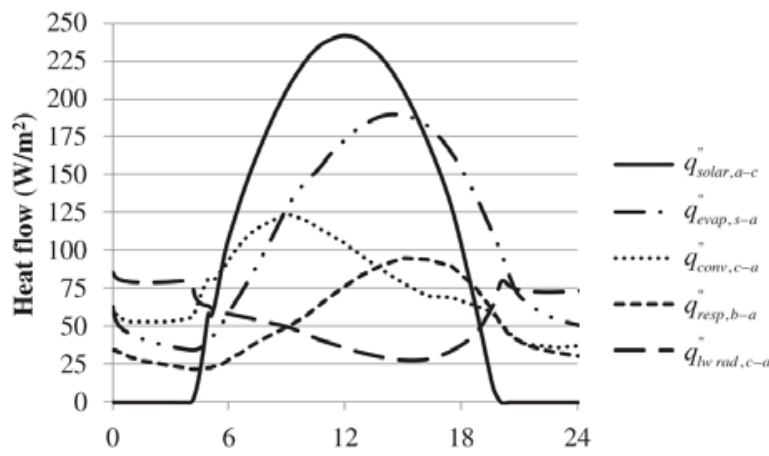

Thompson et al. (2014)

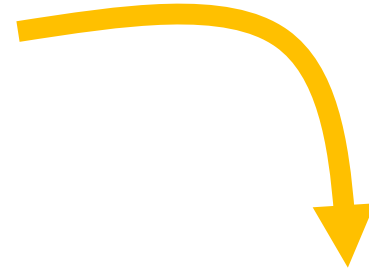

Table 2. Body-core component*

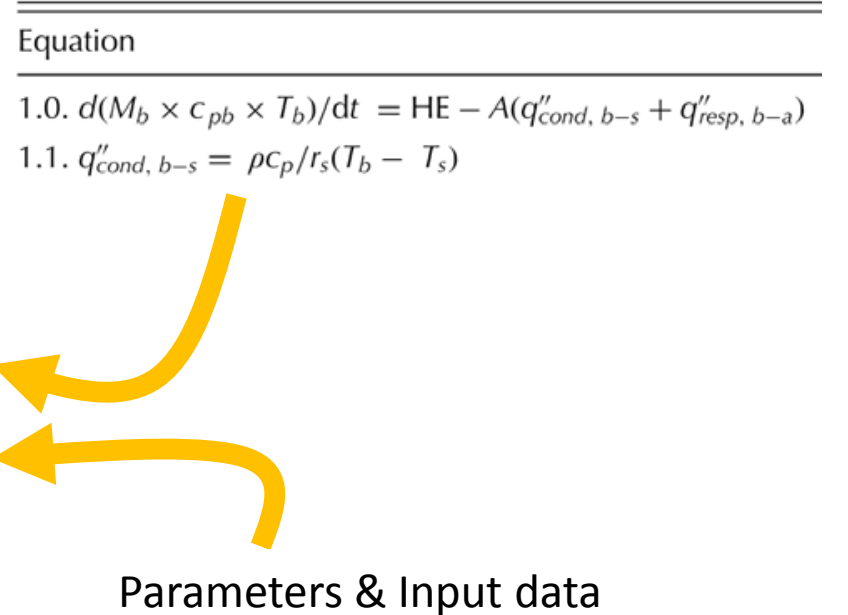




\section{A brief overview of existing models}

- Type II (barn climatic/optimization models)

- Models of environmental conditions around the animal

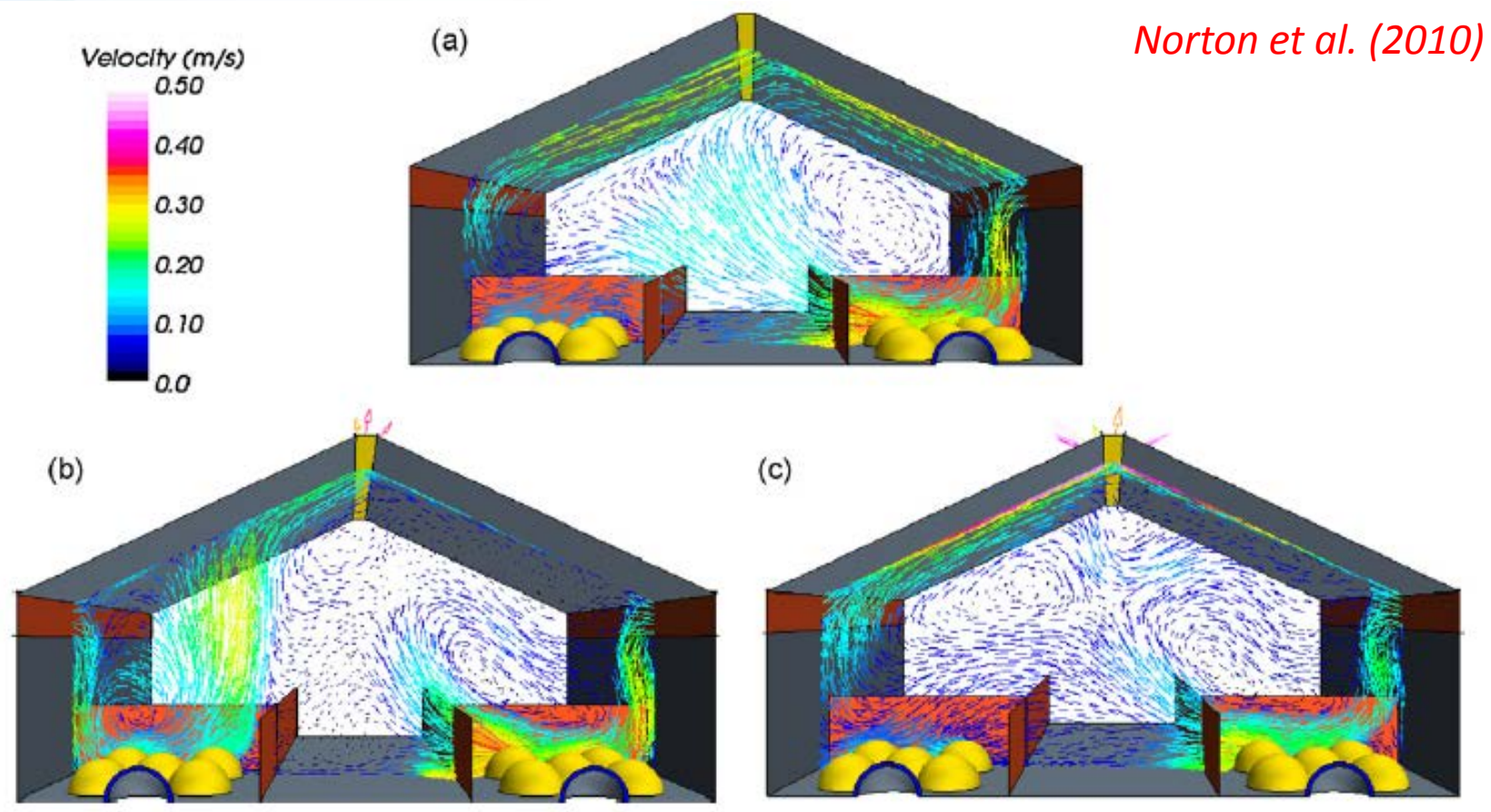

Full modeling of animals microenvironment in barns 


\section{A brief overview of existing models}

- Type III (stress-strain statistical models)
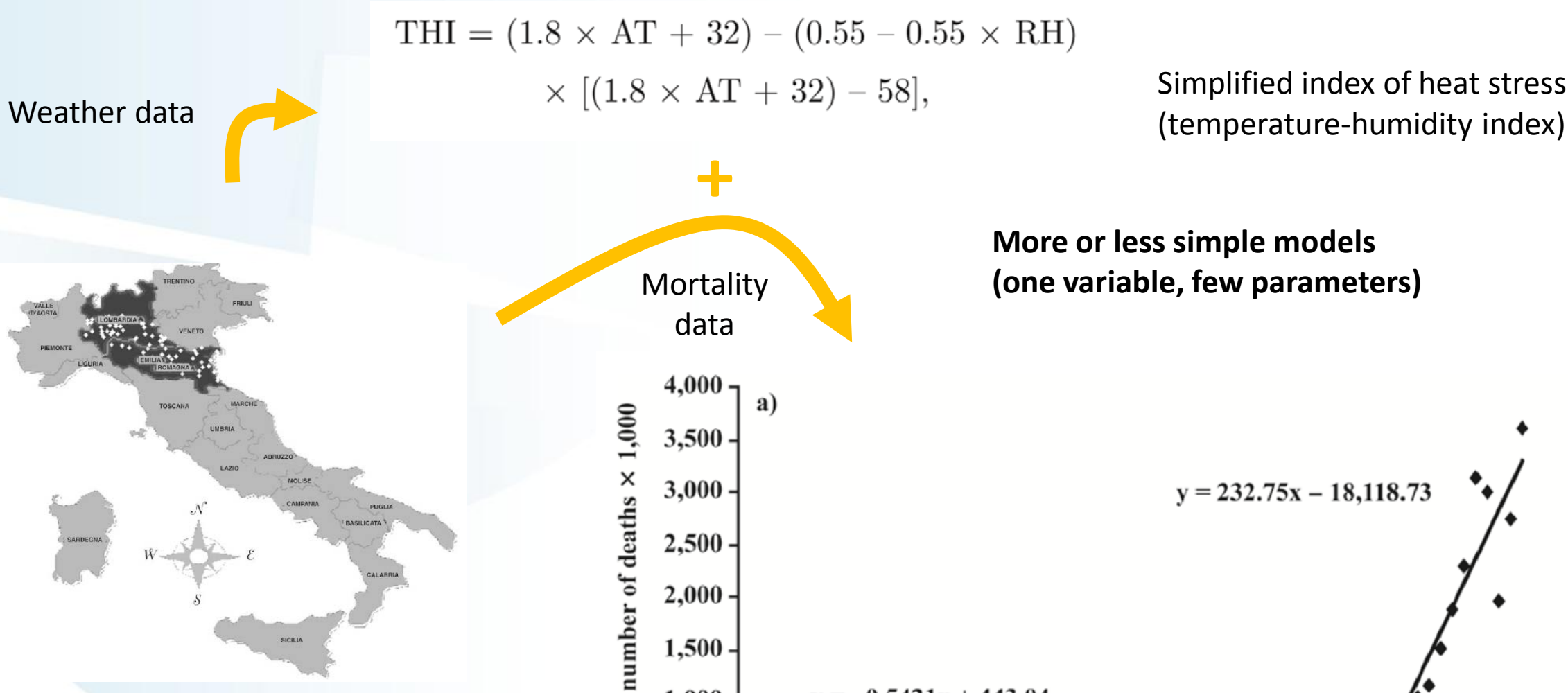

More or less simple models

(one variable, few parameters)

Vitali et al (2009)

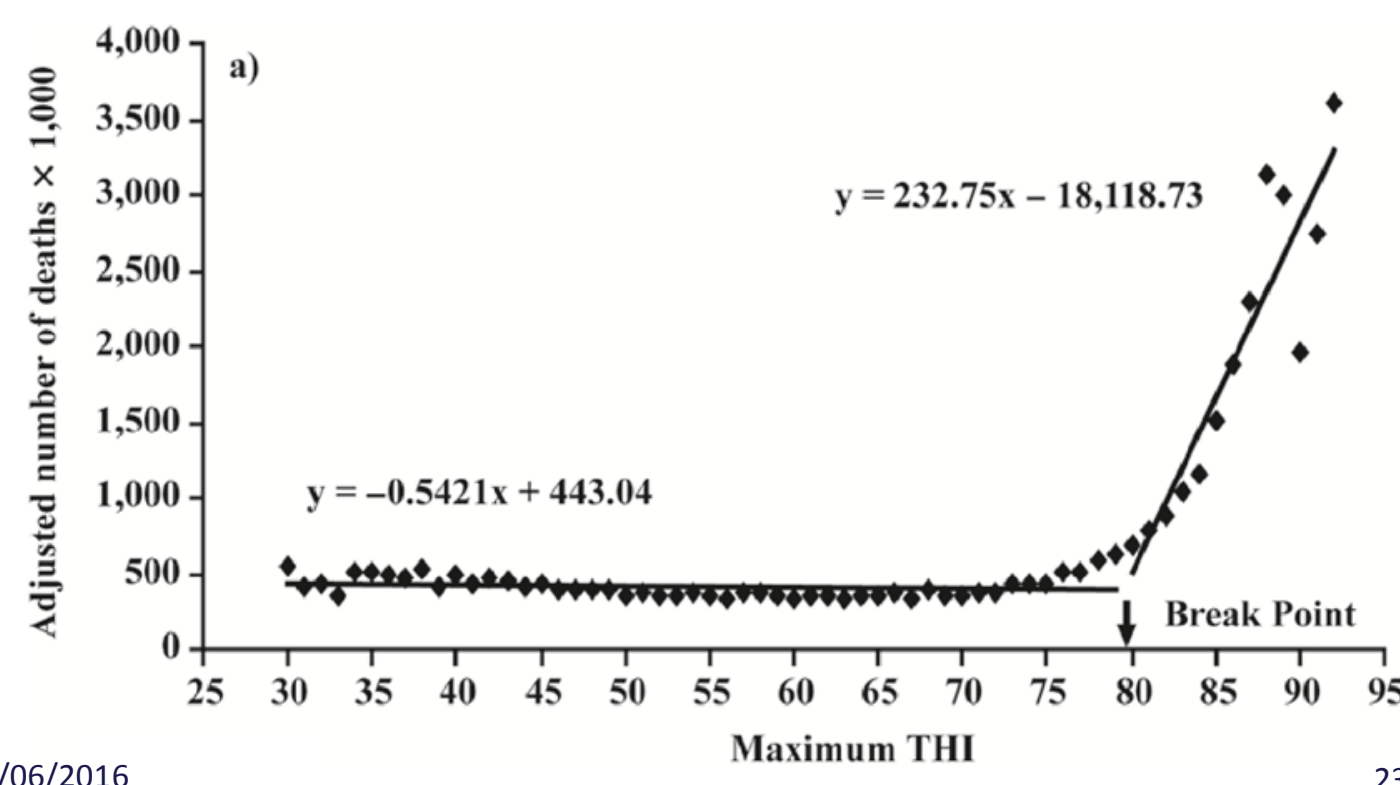




\section{A brief overview of existing models}

- Type IV (monitoring \& early warning)

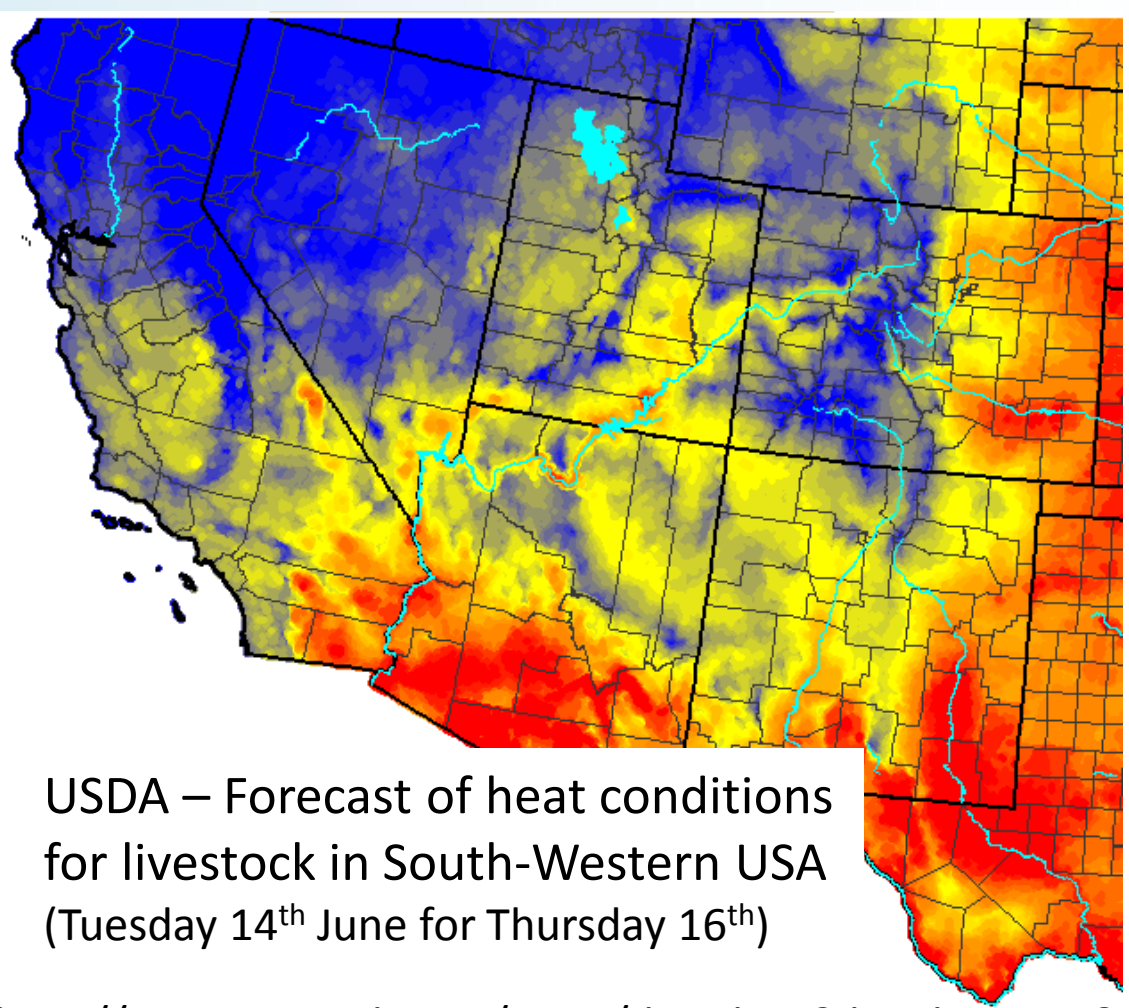

http://www.ars.usda.gov/Main/docs.htm?docid=25274\&viewDay=3

\section{ALER'T}

\section{DANGER}

EMRRGENCY
Weather forecast

+ Computation of simple heat stress metric

+ Classification in risk classes

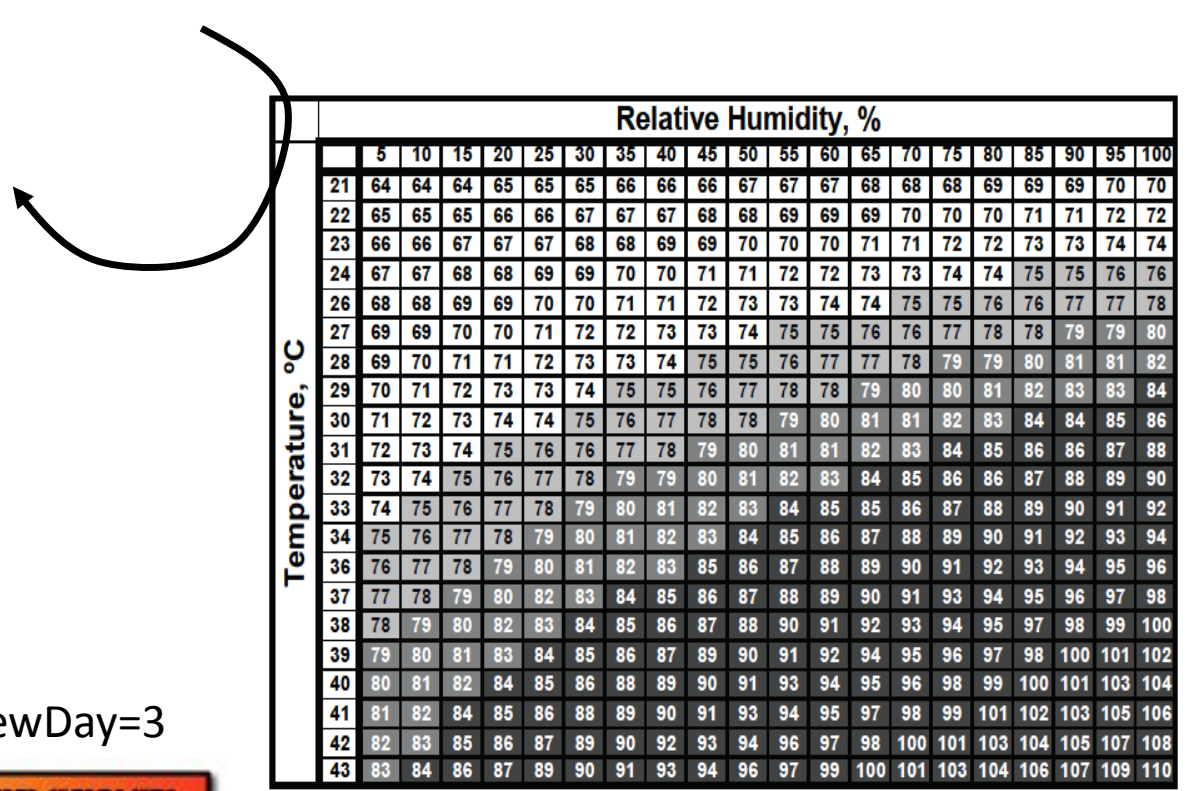

Categories of Livestock Weather Safety Index associated with THI values: Normal: $\leq 74$ Alert: 75-78 Danger: 79-83 Emergency: $\geq 84$

Hahn et al (2009) 


\section{A brief overview of existing models}

- Type V (farm-scale models)

- Modeling farm impacts of altered traits, management options, economic/envtl consequences
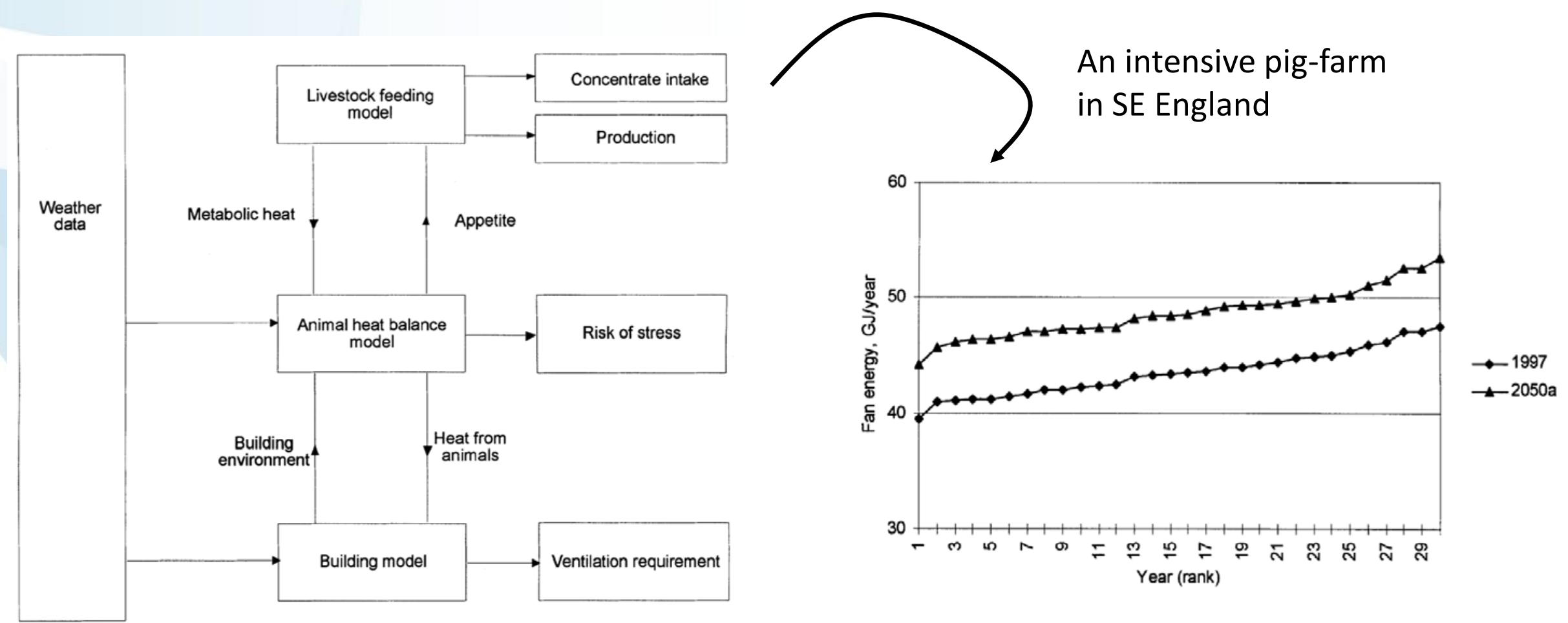

Turnpenny et al (2001) 


\section{A brief overview of existing models}

- Type VI (regional to global economic models)

- Evolution of demand, trade, price, livestock \& production systems

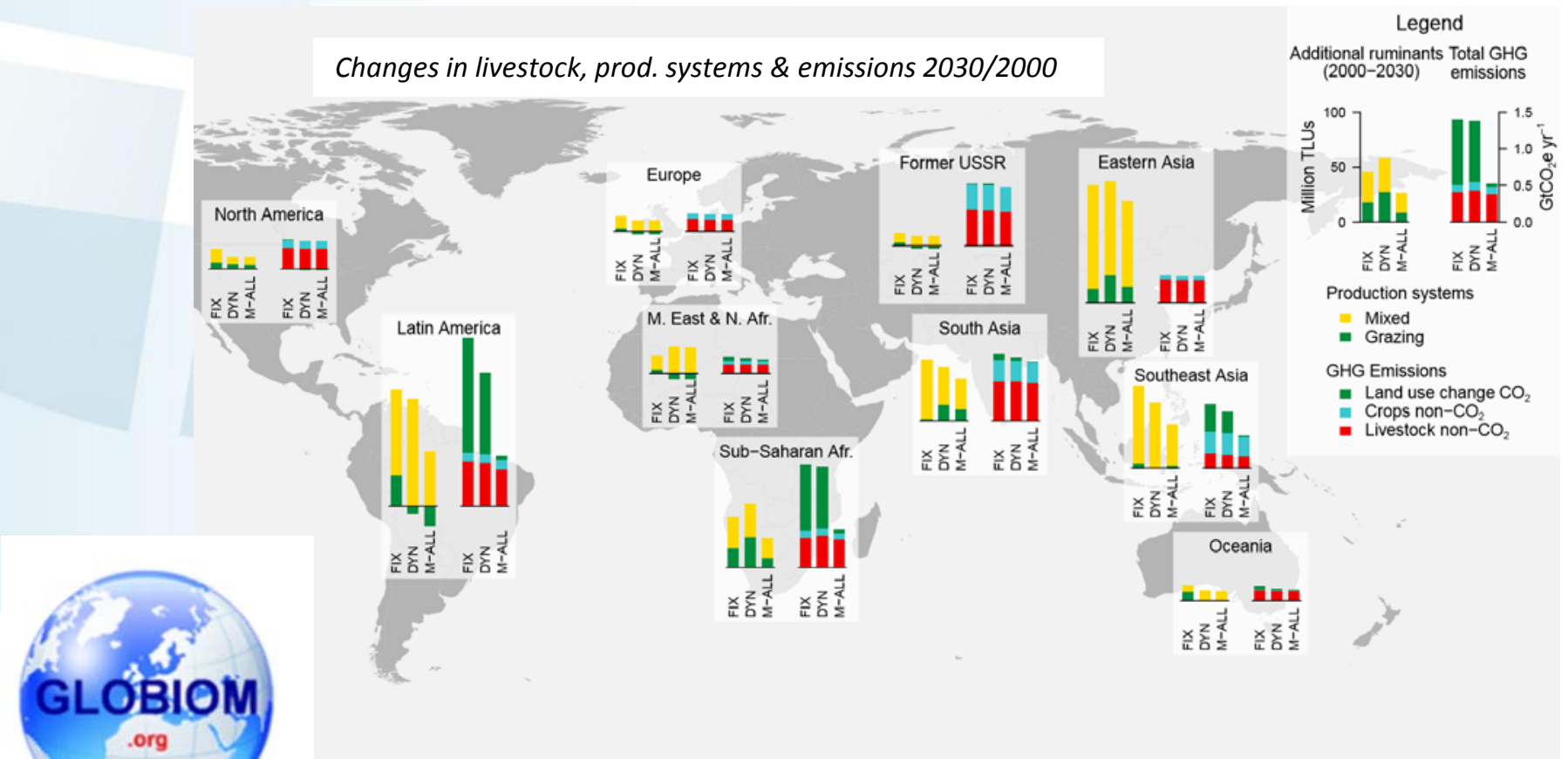

Havlík et al (2014) 


\section{A brief overview of existing models}

- Type VII (genetics)

- Statistical models to explore phenotype \& heat tolerance

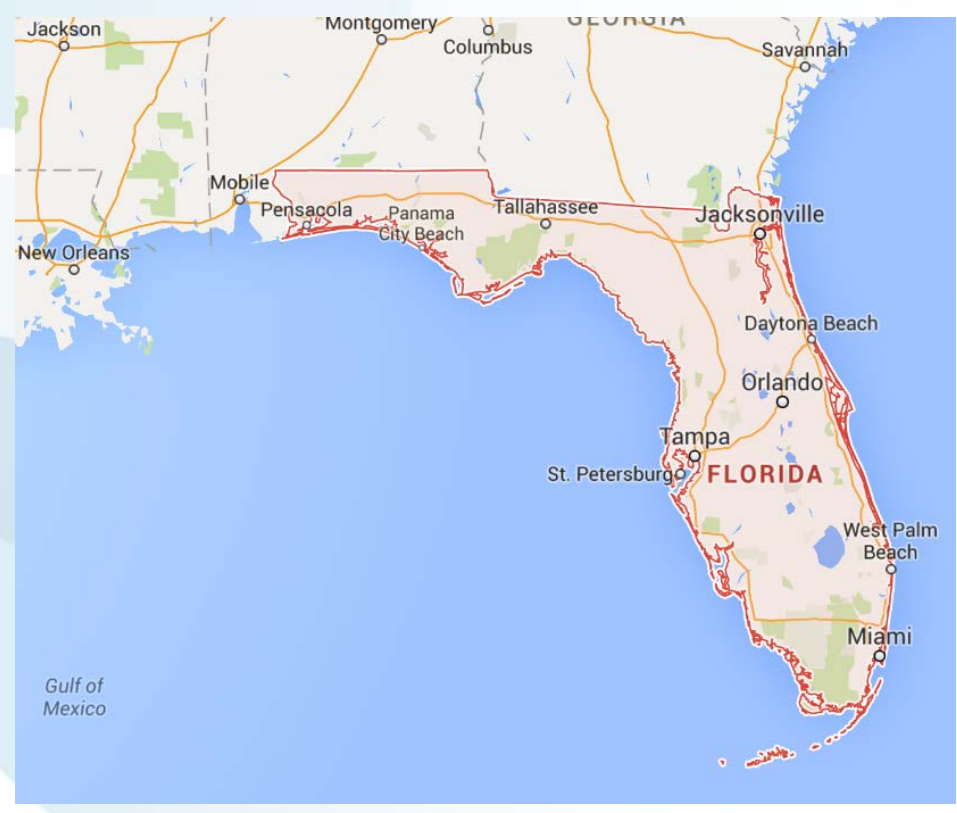

Dikmen et al (2013)
Observation data under heat stress conditions ( 11k cows) with RT \& DNA measurements

+ Genome-wide Quantitative Trait Locus analysis \& statistical model

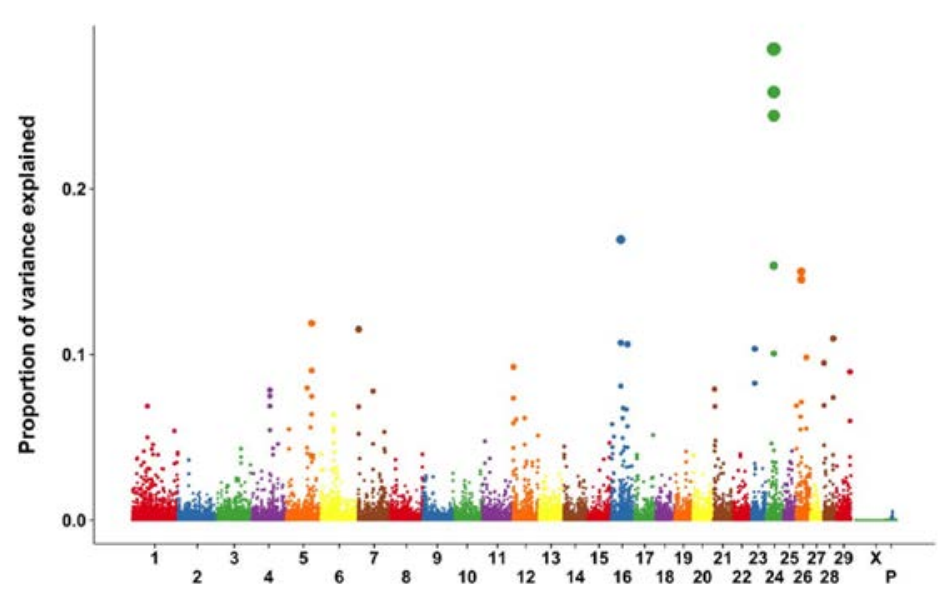




\section{Potential ways forward \& limits}




\section{Potential ways forward \& limits}

- What to do? Connect the extremes

- How to do it? Analogy to crop modelling:

- Gridded approaches (i.e., gridded stat. stress-strain model)

- Genericity (several species/breeds/types of management)

- Point based calibration/validation 


\section{Potential ways forward \& limits}

- What to do? Connect the extremes:

- How to do it? Analogy to crop modelling:

- Limits?

- Limited data availability for parameterization

- Parsimonious approach to harvest from published case studies

- Open-data approach as a strategy?

- Do not valorize model biodiversity

- Adopt modular approaches to allow complexity in data rich envts

- Again open-source as a strategy? 


\section{Conclusion}




\section{Conclusion}

- An important gap in climate change literature

- No quantified estimate of global impact of HS on livestock

- Exposure to heat stress might dramatically increase

- A complex issue where we already have experience

- Many processes to account for in upscaling

- A rich but not well connected array of model types

- Rich experience from other fields such as crop modeling

- A matter of getting people started

- A lot could be done within partners of MACSUR

- Let's talk proposal writing? 


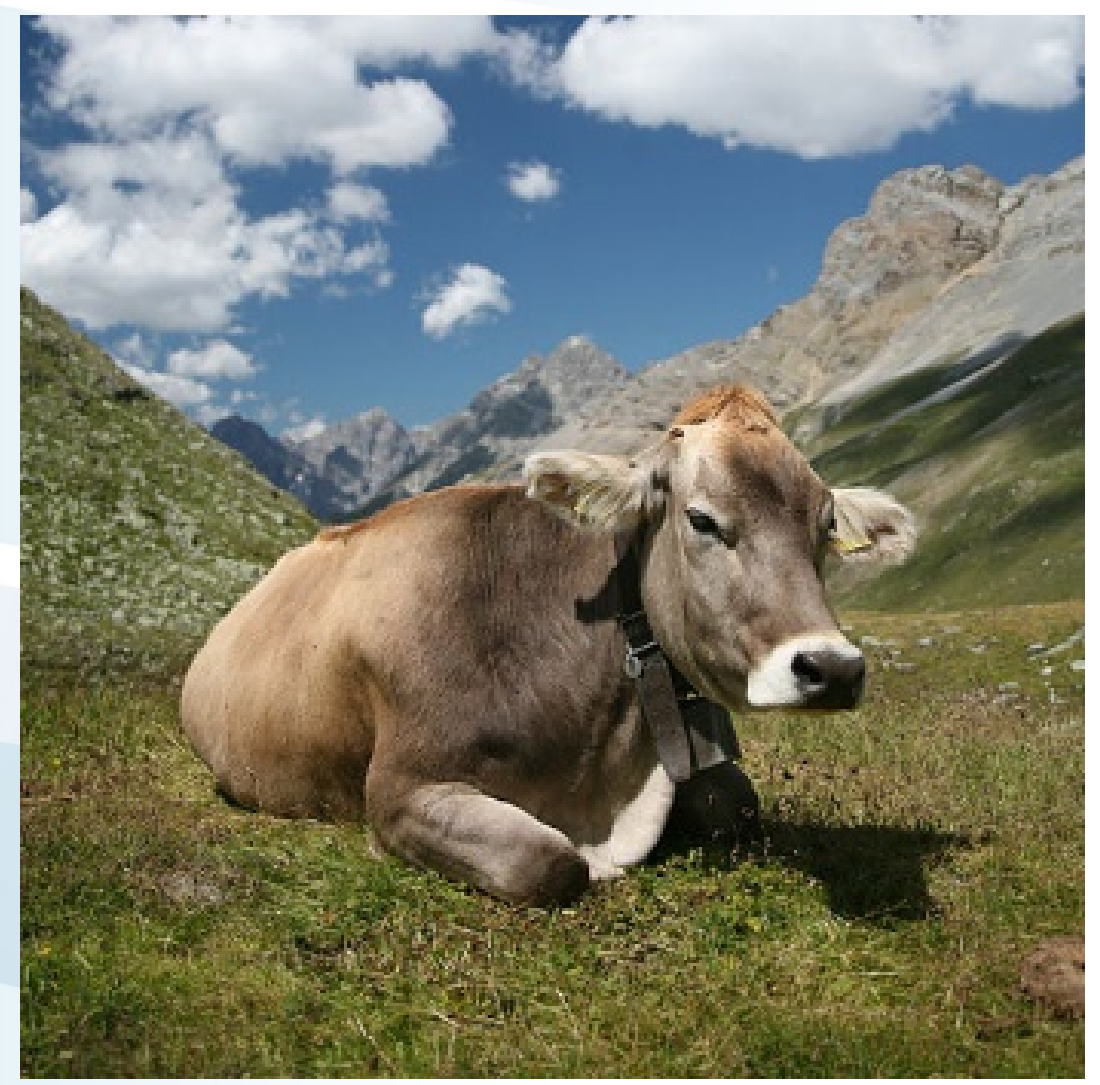

\section{Thank you !}

leclere@iiasa.ac.at www.globiom.org 


\section{References (1)}

- Bianca W 1965 Reviews of the progress of dairy science Section A. Physiology. Cattle in a hot environment. J. Dairy Res. 32 291-345

- Blackshaw J K and Blackshaw A W 1994 Heat stress in cattle and the effect of shade on production and behaviour: a review Aust. J.

Exp. Agric. 34285

- Collier R J and Gebremedhin K G 2015 Thermal biology of domestic animals. Annu. Rev. Anim. Biosci. 3 513-32

- Dikmen S, Cole J B, Null D J and Hansen P J 2013 Genome-Wide Association Mapping for Identification of Quantitative Trait Loci for Rectal Temperature during Heat Stress in Holstein Cattle PLoS One 8 1-7

- Gauly M, Bollwein H, Breves G, Brügemann K, Dänicke S, Daş G, Demeler J, Hansen H, Isselstein J, König S, Lohölter M, Martinsohn M, Meyer U, Potthoff M, Sanker C, Schröder B, Wrage N, Meibaum B, von Samson-Himmelstjerna G, Stinshoff H and Wrenzycki C 2013 Future consequences and challenges for dairy cow production systems arising from climate change in Central Europe - a review Animal 7 843-59

- Hahn G L, Gaughan J B, Mader T L and Eigenberg R A 2009 Chapter 5: Thermal Indices and Their Applications for Livestock Environments Livestock Energetics and Thermal Environmental Management ed J A DeShazer (m: American Society of Agricultural and Biological Engineers) pp 113-30

- Havlík P, Valin H, Herrero M, Obersteiner M, Schmid E, Rufino M C, Mosnier A, Thornton P K, Böttcher H, Conant R T, Frank S, Fritz S, Fuss S, Kraxner F and Notenbaert A 2014 Climate change mitigation through livestock system transitions. Proc. Natl. Acad. Sci. U. S. A. 111 3709-14

- Martinsohn M and Hansen H 2012 The impact of climate change on the economics of dairy farming - A review and evaluation Ger. J. Agric. Econ. 61 80-95

- Norton T, Grant J, Fallon R and Sun D W 2010 Improving the representation of thermal boundary conditions of livestock during CFD modelling of the indoor environment Comput. Electron. Agric. 73 17-36

- Silanikove N 2000 Effects of heat stress on the welfare of extensively managed domestic ruminants Livest. Prod. Sci. 67 1-18

- St-Pierre N R, Cobanov B and Schnitkey G 2003 Economic losses from heat stress by US livestock industries J. Dairy Sci. 86 E52-77

- Thompson V A, Sainz R D, Strathe A B, Rumsey T R and Fadel J G 2014 The evaluation of a dynamic, mechanistic, thermal balance model for Bos indicus and Bos taurus J. Agric. Sci. 152 483-96 


\section{References (2)}

- Turnpenny J ., Wathes C ., Clark J . and McArthur A . 2000 Thermal balance of livestock. 1. A parsimonious model Agric. For. Meteorol. $10129-52$

- Turnpenny J R, Parsons D J, Armstrong A C, Clark J A, Cooper K and Matthews A M 2001 Integrated models of livestock systems for climate change studies. 2. Intensive systems Glob. Chang. Biol. 7 163-70

- Vitali a, Segnalini M, Bertocchi L, Bernabucci U, Nardone a and Lacetera N 2009 Seasonal pattern of mortality and relationships between mortality and temperature-humidity index in dairy cows. J. Dairy Sci. 92 3781-90

- Wang L, Huang J, Luo Y, Yao Y and Zhao Z 2015 Changes in extremely hot summers over the global land area under various warming targets PLoS One $101-11$ 